\title{
Real-time PCR evaluation of cell-free DNA subjected to various storage and shipping conditions
}

\author{
Q. Wang ${ }^{1}$, Y. Cai ${ }^{2}$, P. Brady ${ }^{3}$ and J.R. Vermeesch ${ }^{3}$ \\ ${ }^{1}$ Key Laboratory of Medical Cell Biology, Ministry of Education, \\ Department of Cell Biology, College of Basic Medical Science, \\ China Medical University, Shenyang, China \\ 2Department of Special Inspection, Liaoning Provincial Corps Hospital, \\ Chinese People's Armed Police Forces, Shenyang, China \\ ${ }^{3}$ Laboratory for Cytogenetics and Genome Research, Centre for Human Genetics, \\ KU Leuven, Leuven, Belgium \\ Corresponding author: Q. Wang \\ E-mail: wangqian529@163.com
}

Genet. Mol. Res. 14 (4): 12797-12804 (2015)

Received May 13, 2015

Accepted August 13, 2015

Published October 19, 2015

DOI http://dx.doi.org/10.4238/2015.October.19.23

ABSTRACT. In this study, we attempted to explore the factors affecting the yield of cell-free fetal DNA (cffDNA) obtained from maternal blood samples, including the use of different types of collection tubes, the interval between sample processing, and sample shipping under extreme weather conditions. Blood samples were drawn into $\mathrm{K}_{3}$ EDTA tubes and cellstabilizing tubes (Streck blood collection tube, BCT) from women pregnant with male fetuses. Real time PCR was used to amplify a $\beta$-actin gene fragment to measure the total plasma cell-free DNA concentration, while an SRY gene fragment was used to quantify the cffDNA. The samples in the $\mathrm{K}_{3}$ EDTA tubes revealed a decreased quantity of $S R Y$ after 5 days of transportation, with a median of 25.9 copies $/ \mathrm{mL}(P<0.01)$; however, the value remained stable at 33.4 copies $/ \mathrm{mL}$ in the BCT tubes. We observed a statistically significant increase in stability of the amount of total DNA in the 
blood samples stored in $\mathrm{K}_{3}$ EDTA tubes $(\mathrm{P}<0.01)$ and transportated under extreme outdoor temperatures $\left(-20^{\circ}-0^{\circ} \mathrm{C}\right)$ than that of the control values. These results indicate that it could be possible to avoid the presence of excess maternal DNA in samples shipped under extreme weather conditions for no more than 2 days, by collecting the blood samples in BCT tubes.

Key words: Maternal plasma; Cell-free DNA; Yield; Temperature

\section{INTRODUCTION}

The discovery of circulating cell-free fetal DNA (cffDNA) in maternal circulation opens up new possibilities for non-invasive prenatal diagnosis (Lo et al., 1997; Alberry et al., 2007). Although the origin of cffDNA has not yet been completely understood, several studies support the hypothesis that cffDNA arises from trophoblasts in the placenta (Flori et al., 2004). Maternal plasma contains circulating cell-free DNA fragments originating from both the mother and the placenta. cffDNA derived from the placenta is known as the fetal fraction. The average fetal fraction in the maternal plasma is $10-15 \%$ when measured between gestational weeks 10 and 20; however, this can also range from under $3 \%$ to over $30 \%$ (Huang et al., 2008). Previous research has shown that cffDNA is rapidly cleared from maternal circulation after delivery; this contributed to the emerging interest in cffDNA as a potential marker for prenatal diagnosis (Romao et al., 1992; Thomas et al., 1995). Many researchers have explored the possibility of using cffDNA in the non-invasive prenatal diagnosis (NIPD) of fetal sex, RhD blood typing, aneuploidy, and single gene disorders, such as cystic fibrosis and Huntington's disease (Bustamante et al., 2008; Norbury et al., 2008; Buysse et al., 2013; Oxenford et al., 2013). cffDNA is present in very low quantities in the body; therefore, it is important to optimize cffDNA yields when considering it for clinical diagnosis. Several factors should be taken into account in order to achieve this goal, including the type of kit used to extract DNA from the plasma samples, the time interval between drawing of the blood and sample processing for each individual, stable collection tubes, and the possibility that samples may be shipped prior to processing.

The most common method for the evaluation of cffDNA is through the detection of Y-chromosome-specific DNA (SRY gene) in the maternal circulatory system using real time PCR, which is the method used in this study. However, this method is not optimal for clinical analyses, as it cannot be applied to nearly $50 \%$ of the population. New approaches based on digital PCR, which can amplify fragments $>300 \mathrm{bp}$, have been previously reported (Norton et al., 2008). Additional studies have shown that true cffDNA fragments are generally $<200$ bp-long, likely because of cellular apoptosis (Chan et al., 2004). An increase in the concentration of fragments that are $>300$ bp-long may be an indication of a compromised blood sample wherein the maternal leukocytes have released their genomic DNA (Lambert et al., 2002).

In this study, we have evaluated the factors that may influence the yield of cffDNA. This could facilitate the development of standards required for the implementation of this technology in routine clinical practice.

\section{MATERIAL AND METHODS}

\section{Subject enrollment}

Women who were pregnant with male fetuses undergoing amniocentesis or chorionic villus 
sampling and exhibiting a high risk of fetal chromosomal defects, and couples with a clinical history of gender-associated disorders referred to the Centre for Prenatal Diagnosis, Shengjing Hospital of China Medical University and the Human Genetics department, Catholic University of Leuven between October 2011 and May 2013 were included in this study. The study was approved by the ethics commissions of both Universities. Each recruited pregnant woman received genetic counseling and was requested to sign an informed consent form. All pregnancies were single pregnancies.

\section{Sample preparation}

The effects of extreme outdoor temperatures and transportation time on DNA concentrations were analyzed to explore the possibility of shipping blood samples to a large centralized and standardized high throughput processing site. Two $10 \mathrm{~mL}$ blood samples were collected from 100 pregnant women to examine the effects of shipping on total blood. The first tube was processed immediately (control), and the second was placed in foam, packed in Styrofoam boxes, and shipped for 2 or 5 days under temperature conditions ranging from $0^{\circ}$ to $10^{\circ} \mathrm{C}$. The concentration of DNA in blood exposed to outdoor temperatures $\left(0^{\circ}-30^{\circ} \mathrm{C}\right.$ and $\left.-20^{\circ}-0^{\circ} \mathrm{C}\right)$ was also determined using the same scheme. Two $10 \mathrm{~mL}$ blood samples were collected from 120 pregnant women to examine the effects of shipping on the characteristics of total blood. The first tube was processed immediately (control), and the second was placed in foam, packed in Styrofoam boxes, and shipped to the north of China (delivery in $48 \mathrm{~h}$ ). The blood samples from all subjects were divided and stored in two tubes: a BCT tube and a $\mathrm{K}_{3}$ EDTA tube at each time point; both samples were analyzed to determine the effect of each type of storage tube on the characteristics of blood.

\section{DNA extraction}

Plasma was separated from the blood cells by centrifugation at $2000 \mathrm{~g}$ for 10 minutes; the clear plasma phase on top was transferred to a new tube, and centrifuged at $14000 \mathrm{~g}$. The supernatant was transferred to a fresh tube for DNA extraction. DNA was extracted from plasma (5 mL) using the QIAamp Circulating Nucleic Acid (CNA) kit (QIAamp Circulating Nucleic Acid kit, Qiagen, Venlo, Netherlands) according to the manufacturer protocols. Lysis buffer was added to the extension tubes, which were placed directly onto the columns. The columns containing the plasma and lysis buffer were placed on a vacuum manifold (Qiagen), and the liquid was drawn through the column using a vacuum pump (and not centrifuged). The DNA was eluted in a final volume of $50 \mu \mathrm{L}$.

\section{Real-time PCR}

The SRY gene in each sample was evaluated using real time PCR on a Roche LightCycler 480 (Roche Diagnostics, Basel, Switzerland). The SRY primer and probe sequences were obtained from Lo et al. (1998). Amplification was performed in a $25 \mu \mathrm{L}$ reaction mixture containing $10 \mu \mathrm{L}$ extracted DNA, 1X LightCycler 480 Probes Master, 200 nM forward primer, 200 nM reverse primer, $100 \mathrm{nM}$ hydrolysis probe, and 0.38 units of uracil-N-glycosylase (Invitrogen, Cergy-Pontoise, France). Two positive ( $\beta$-actin) and three negative (blank) controls were used for each set of reactions; all samples were tested thrice in duplicate. The cycling parameters were set as follows: an initial denaturation step at $95^{\circ} \mathrm{C}$ for $15 \mathrm{~min}, 40$ cycles at $99^{\circ} \mathrm{C}$ for $2 \mathrm{~min}, 65^{\circ} \mathrm{C}$ for $2 \mathrm{~min}$, and $72^{\circ} \mathrm{C}$ for $3 \mathrm{~min}$, and a final extension step at $72^{\circ} \mathrm{C}$ for $10 \mathrm{~min}$. Five percent of the samples were repeated to ensure quality control. 


\section{Statistical analysis}

The paired-test was used to evaluate the differences between samples processed immediately and after transportation. All statistical calculations were performed using the SPSS software (IBM, Armonk, NY, USA). P values $<0.05$ were considered to be significant.

\section{RESULTS}

\section{Sample transportation time}

The experiments were performed between 0 and $10^{\circ} \mathrm{C}$. The median gestational age of plasma samples was 13 weeks. The amount of SRY DNA originating from the male fetus, detected in the plasma of the immediately processed blood samples collected in standard $\mathrm{K}_{3}$ EDTA and BCT tubes, corresponded to a median of 31 and 33 copies $/ \mathrm{mL}$, respectively. The results of samples processed for $0.5 \mathrm{~h}$ did not differ significantly between the BCT and the standard $\mathrm{K}_{3}$ EDTA tubes. The samples collected in the $\mathrm{K}_{3}$ EDTA tubes detected a lower amount of SRY after 5 days of transportation, with a median of 25.9 copies $/ \mathrm{mL}(P<0.01)$; however, the value remained stable at $33.4 \mathrm{copies} / \mathrm{mL}$ in $\mathrm{BCT}$ tubes (Figure 1A). We also observed a significant increase $(P<0.01)$ in the total DNA levels in the samples collected in the $\mathrm{K}_{3}$ EDTA tubes (Figure 1B). The samples tested after 2 days of transportation did not show any significant differences in results between the two tubes.
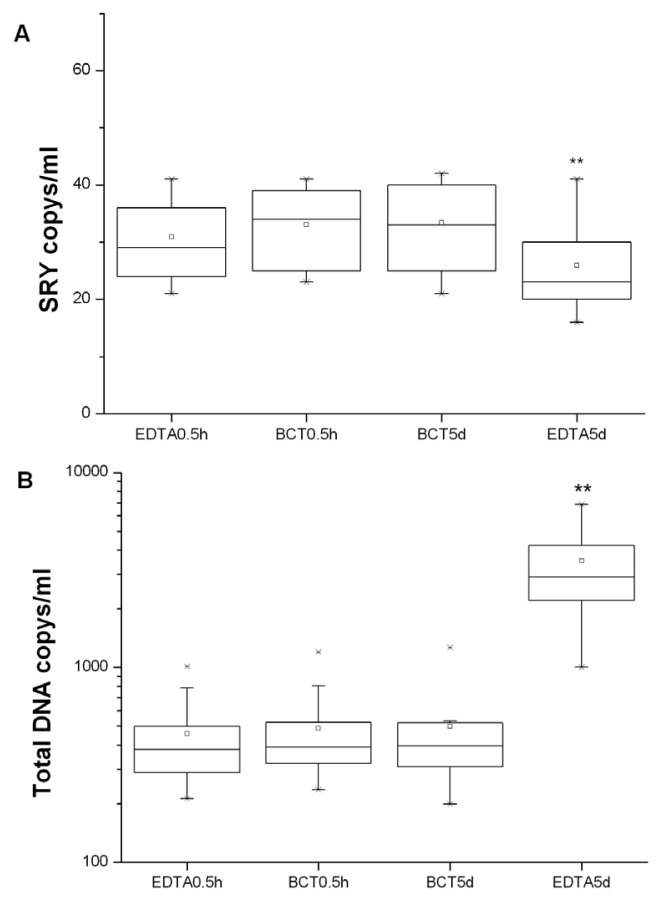

Figure 1. Cell-free fetal DNA expression determined using a Y-chromosome-specific SRY real-time polymerase chain reaction (PCR) method; values are expressed as copies per $\mathrm{mL}$ plasma. $\mathbf{A}$. The amount of male cffDNA from the immediately-processed- and 5-day-samples collected in the K3EDTA and BCT tubes. B. The amount of total cell-free circulating DNA in the K3EDTA and BCT tubes. 


\section{Effect of outdoor temperatures on the samples}

There was no significant difference in the concentration of male cffDNA between the control and shipped BCT tubes under extreme outdoor temperatures $\left(-20^{\circ}-0^{\circ} \mathrm{C}\right)$, whereas a decrease was observed in the $\mathrm{K}_{3}$ EDTA tubes after shipment (from a median of 29.1 copies $/ \mathrm{mL}$ to 24.4 copies/ $\mathrm{mL}$ ). However, we observed a statistically significant increase in the amount of total DNA in the shipped $\mathrm{K}_{3}$ EDTA blood samples $(\mathrm{P}<0.01)$ compared to the control samples after transportation (Figure $2 \mathrm{~A}$ ). The concentration of male cffDNA in the control and shipped $\mathrm{K}_{3}$ EDTA and BCT tubes decreased slightly under extreme outdoor temperature conditions $\left(0^{\circ}-30^{\circ} \mathrm{C}\right.$; Figure $\left.2 \mathrm{~B}\right)$, while the concentration of total DNA increased in the $\mathrm{K}_{3}$ EDTA and BCT tubes. The median gestational age of the pregnancies tested in this group was $13+5$ weeks.
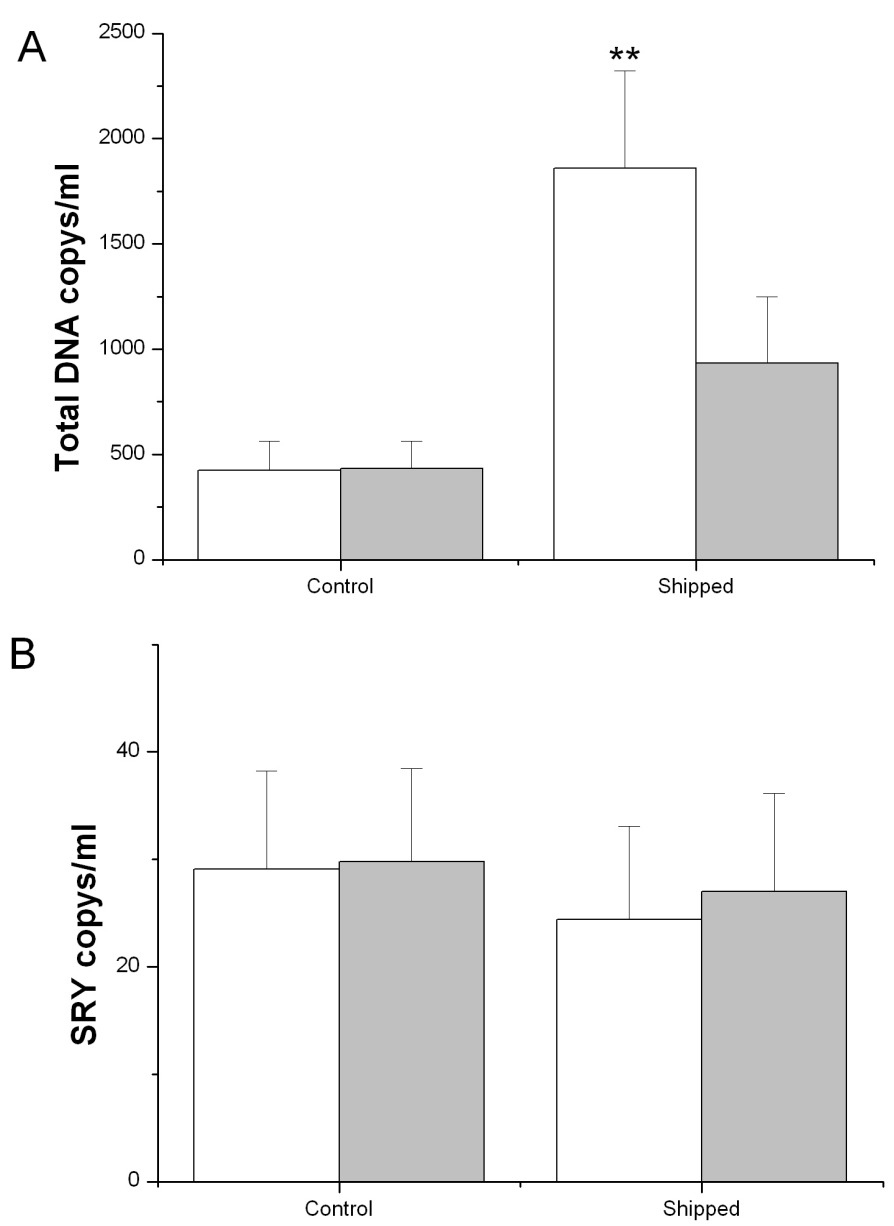

Figure 2. Effect of shipping on the concentrations of total DNA (temperature $-20^{\circ}-0^{\circ} \mathrm{C}$ ) and male cffDNA (temperature $0^{\circ}-30^{\circ} \mathrm{C}$ ) in blood. The concentrations of $(\mathbf{A})$ male cffDNA and $(\mathbf{B})$ total DNA were determined by real time PCR. We observed a statistically significant increase in the total DNA level in the shipped samples that were initially drawn into K3EDTA tubes (white bars). The same samples drawn into BCT tubes (gray bars) showed no statistically significant changes in the concentration of male cffDNA. 


\section{DISCUSSION}

The most effective method of preventing the release of genomic DNA into the plasma fraction is its immediate processing after phlebotomy; however, the need for immediate processing limits the diagnostic use of cffDNA, particularly in local clinics lacking the laboratory equipment and expertise needed for plasma processing (Chan et al., 2005). Therefore, factors that influence the quantity of cffDNA have been investigated, including the time interval between the drawing of the blood and plasma processing (Angert et al., 2003; Xue et al., 2009), the type of collection tube used (Banfi et al., 2007), and the safe transport of specimens.

The $\beta$-actin gene was used to calculate the total copy number of DNA per mL plasma; the SRY gene assay indicated the total quantity of male cffDNA in the sample. In the first series of transportation time experiments, individual blood samples prepared at different time intervals after transportation were analyzed. The samples analyzed when delivered after 2 days showed no significant changes. The samples in $\mathrm{K}_{3}$ EDTA tubes analyzed after 5 days of transportation showed a lower concentration of the SRY gene, with a median of 25.9 copies $/ \mathrm{mL}(P<0.01)$. This could be attributed to either cffDNA breakdown or disturbances caused as a result of excess maternal DNA. Clausen et al. (2103) reported that neither the levels nor the detection of cffDNA was affected by the transportation of blood samples for up to 9 days, despite a substantial elevation in total DNA. A major factor to be considered is that as the blood samples were collected at a gestational age of 25 weeks, a greater amount of cffDNA was released into maternal blood. However, several studies have also shown that cffDNA is stable within the first 24 hours after sample collection (Angert et al., 2003; Zhang et al., 2008; Barrett et al., 2011). Based on the results of our study, it could be concluded that cffDNA was stable in blood samples for up to 2 days in both tubes. In the second series of temperature-related experiments, we observed a slight decrease in cffDNA quantity in the $\mathrm{K}_{3}$ EDTA collection tubes after shipment (median of 29.1 to 24.4 copies $/ \mathrm{mL}$ ) under extreme outdoor temperatures $\left(-20^{\circ}-0^{\circ} \mathrm{C}\right)$. An increase or decrease of less than $5 \mathrm{copies} / \mathrm{mL}$ is not a great number, especially considering a realistic increase or decrease. We observed a statistically significant increase in the amount of total DNA in the shipped $K_{3}$ EDTA blood samples $(P<0.01)$ compared to the control values after 2 days of transportation under extreme outdoor temperatures $\left(-20^{\circ}-0^{\circ} \mathrm{C}\right)$, indicating the release of a greater quantity of DNA from the maternal cells. Hidestrand et al. (2012) reported the influence of temperature during transportation in cell-free DNA analysis; however, their study did not include performed in extreme cold outdoor temperatures $\left(<0^{\circ} \mathrm{C}\right)$. This is the first study analyzing the effect of shipping under extreme outdoor temperatures $\left(-20^{\circ}-0^{\circ} \mathrm{C}\right)$ on blood samples. The major limitation of our study is that environmental indicators were not included in the shipment box as a precaution; this must be done to avoid making interpretations of false results obtained as a result of exposure to unfavorable temperatures and shipping conditions.

Barrett et al. (2011) reported no differences in the proportion of fetal DNA in plasma extracted from cells stored in $\mathrm{K}_{3}$ EDTA or BCT tubes at four and eight hours after drawing of the blood; however, they reported significant benefits to the use of BCT tubes for $\geq 24$ hours of storage. In this study, the use of BCT and $\mathrm{K}_{3}$ EDTA tubes for storage of plasma samples to be shipped under extreme weather conditions was compared; the results of this study confirmed that samples stored in BCT tubes gave better results when shipped and delivered after 2 days. BCT tubes would, therefore, be the first choice for the shipping of samples under temperatures of $-20^{\circ}-0^{\circ} \mathrm{C}$. Fernando et al. (2012) also reported that BCT tubes could maintain the proportion of cell-free DNA over long periods of time; this was confirmed in our studies.

In conclusion, the presence of excess maternal DNA could be avoided during shipment 
under extreme weather conditions for no more than 2 days by collecting the blood samples in BCT tubes. The determination of factors that could influence the yield of cffDNA could assist in the development of a non-invasive prenatal diagnostic technique utilizing cffDNA.

\section{Conflicts of interest}

The authors declare no conflict of interest.

\section{ACKNOWLEDGMENTS}

Research supported by grants provided by the Natural Science Foundation of Liaoning Province (\#2014021043) and the Science \& Technology Project of the Education Department of Liaoning Province (\#L2014311)

\section{REFERENCES}

Alberry M, Maddocks D, Jones M, Abdel Hadi M, et al. (2007). Free fetal DNA in maternal plasma in anembryonic pregnancies: confirmation that the origin is the trophoblast. Prenat. Diagn. 27: 415-418.

Angert RM, LeShane ES, Lo YM, Chan LY, et al. (2003). Fetal cell-free plasma DNA concentrations in maternal blood are stable 24 hours after collection: analysis of first- and third-trimester samples. Clin. Chem. 49: 195-198.

Banfi G, Salvagno GL and Lippi G (2007). The role of ethylenediamine tetraacetic acid (EDTA) as in vitro anticoagulant for diagnostic purposes. Clin. Chem. Lab. Med. 45: 565-576.

Barrett AN, Zimmermann BG, Wang D, Holloway A, et al. (2011). Implementing prenatal diagnosis based on cell-free fetal DNA: accurate identification of factors affecting fetal DNA yield. PloS One 6: e25202.

Bustamante-Aragones A, Trujillo-Tiebas MJ, Gallego-Merlo J, Rodriguez de Alba M, et al. (2008). Prenatal diagnosis of Huntington disease in maternal plasma: direct and indirect study. Eur. J. Neurol. 15: 1338-1344.

Buysse K, Beulen L, Gomes I, Gilissen C, et al. (2013). Reliable noninvasive prenatal testing by massively parallel sequencing of circulating cell-free DNA from maternal plasma processed up to 24 hours after venipuncture. Clin. Biochem. 46: 1783-1786.

Chan KC, Zhang J, Hui AB, Wong N, et al. (2004). Size distributions of maternal and fetal DNA in maternal plasma. Clin. Chem. 50: 88-92.

Chan KC, Yeung SW, Lui WB, Rainer TH, et al. (2005). Effects of preanalytical factors on the molecular size of cell-free DNA in blood. Clin. Chem. 51: 781-784.

Clausen FB, Jakobsen TR, Rieneck K, Krog GR, et al. (2013). Pre-analytical conditions in non-invasive prenatal testing of cellfree fetal RHD. PloS One 8: e76990.

Fernando MR, Chen K, Norton S, Krzyzanowski G, et al. (2010). A new methodology to preserve the original proportion and integrity of cell-free fetal DNA in maternal plasma during sample processing and storage. Prenat. Diagn. 30: 418-424.

Flori E, Doray B, Gautier E, Kohler M, et al. (2004). Circulating cell-free fetal DNA in maternal serum appears to originate from cyto- and syncytio-trophoblastic cells. Hum. Reprod. 19: 723-724.

Hidestrand M, Stokowski R, Song K, Oliphant A, et al. (2012). Influence of temperature during transportation on cell-free DNA analysis. Fetal Diagn. Ther. 31: 122-128.

Huang DJ, Mergenthaler-Gatfield S, Hahn S, Holzgreve W, et al. (2008). Isolation of cell-free DNA from maternal plasma using manual and automated systems. Meth. Mol. Bio. 444: 203-208.

Lambert NC, Lo YM, Erickson TD, Tylee TS, et al. (2002). Male microchimerism in healthy women and women with scleroderma: cells or circulating DNA? A quantitative answer. Blood 100: 2845-2851.

Lo YM, Corbetta N, Chamberlain PF, Rai V, et al. (1997). Presence of fetal DNA in maternal plasma and serum. Lancet 350: 485-487.

Lo YM, Tein MS, Lau TK, Haines CJ, et al. (1998). Quantitative analysis of fetal DNA in maternal plasma and serum: implications for noninvasive prenatal diagnosis. Am. J. Hum. Genet. 62: 768-775.

Norbury G and Norbury CJ (2008). Non-invasive prenatal diagnosis of single gene disorders: how close are we? Semin. Fetal Neonat. M. 13: 76-83.

Norton SE, Lechner JM, Williams T and Fernando MR (2013). A stabilizing reagent prevents cell-free DNA contamination by cellular DNA in plasma during blood sample storage and shipping as determined by digital PCR. Clin. Biochem. 46: 1561-1565. 
Oxenford K, Silcock C, Hill M and Chitty L (2013). Routine testing of fetal Rhesus D status in Rhesus D negative women using cell-free fetal DNA: an investigation into the preferences and information needs of women. Prenat. Diagn. 33: 688-694.

Romao RM, Levi JE, Carvalho HB, Francisco RP, et al. (1992). Use of cell-free fetal nucleic acids in maternal blood for prenatal diagnosis: the reality of this scenario in Brazil. Rev. Assoc. Med. Bras. 58: 615-619.

Thomas MR, Tutschek B, Frost A, Rodeck CH, et al. (1995). The time of appearance and disappearance of fetal DNA from the maternal circulation. Prenat. Diagn. 15: 641-646.

Xue X, Teare MD, Holen I, Zhu YM, et al. (2009). Optimizing the yield and utility of circulating cell-free DNA from plasma and serum. Clin. Chim. Acta 404: 100-104.

Zhong XY, Laivuori H, Livingston JC, Ylikorkala O, et al. (2008). Effect of formaldehyde treatment on the recovery of cell-free fetal DNA from maternal plasma at different processing times. Clin. Chim. Acta 397: 60-64. 